Keywords: Hb M-Iwate, Cyanosis, Methemoglobinemia

Anahtar Sözcükler: Hb M-Iwate, Siyanoz, Methemoglobinemi

Conflict of Interest: The authors of this paper have no conflicts of interest, including specific financial interests, relationships, and/or affiliations relevant to the subject matter or materials included.

\section{References}

1. Ashurst J, Wasson M. Methemoglobinemia: a systematic review of the pathophysiology, detection, and treatment. Del Med J 2011;83:203-208.

2. Thom CS, Dickson CF, Gell DA, Weiss MJ. Hemoglobin variants: biochemical properties and clinical correlates. Cold Spring Harb Perspect Med 2013;3:a011858.
3. Altay Ç. Abnormal hemoglobins in Turkey. Turk J Hematol 2002;19:63-74.

4. Akar $E_{1}$ Akar N. A review of abnormal hemoglobins in Turkey. Turk J Hematol 2007;24:143-145.

5. Akar N. An updated review of abnormal hemoglobins in the Turkish population. Turk J Hematol 2014;31:97-98.

6. Ozsoylu S. Congenital methemeoglobinemia due to hemoglobin M. Acta Haematol 1972;47:225-232.

7. Shibata S, Tamura A, luchi I, Takahashi H. Hemoglobin MI: demonstration of a new abnormal hemoglobin and hereditary nigremia. Acta Haematol Jap 1960;23:96-105.

8. Shibata S, Miyaji T, Ohba Y. Abnormal hemoglobins in Japan. Hemoglobin 1980;4:395-408.

\title{
Hodgkin Lymphoma, Tuberculosis, and Atypical Radiologic Image
} Hodgkin Lenfoma, Tüberküloz ve Atipik Radyolojik Görüntü

\author{
(1) Sora Yasri1 ${ }^{1}$ (1) Viroj Wiwanitkit² \\ ${ }^{1}$ KMT Primary Care Center, Bangkok, Thailand \\ 2Joseph Ayobabalola University, Ikeji-Arakeji, Nigeria
}

To the Editor,

We read the report by Büyükşimşek et al., [1] "Atypical Radiologic Image Characterized by Cavitary Lung Lesions in a Case of Hodgkin Lymphoma" (HL), with great interest. Büyükşimşek et al. [1] reported on a case of HL presenting with abnormal lung radiologic imaging and mentioned that "Disseminated cavitary lesions mimicking tuberculosis or other opportunistic infections in a case of $\mathrm{HL}$ is interesting and differential diagnosis is very important". We would like to share our ideas regarding this observation. Indeed, lung involvement due to lymphoma is possible. Nevertheless, the concurrence between $\mathrm{HL}$ and tuberculosis is detectable. In endemic areas of tuberculosis, such as Southeast Asia, tuberculosis screening is routinely done for any cancerous patients, including those with HL. Pathophysiologically, a common pathway that can result in increased risk for tuberculosis among patients with $\mathrm{HL}$ is the alteration of the antioxidative system. The depletion of glutathione (GSH) due to $\mathrm{HL}$ [2] can increase the risk for tuberculosis since GSH plays an important role in defending against mycobacterial pathogens [3]. Considering the present report by Büyükşimşek et al., [1] there is an interesting question of whether the present case of HL had a concurrent tuberculosis infection or not. Büyükşimşek et al. [1] used the QuantiFERON test for exclusion of tuberculosis. In a recent report, the sensitivity and specificity of the QuantiFERON test were found to be poor [4]. In cases with underlying vitamin B12 deficiency, false negative results by QuantiFERON are possible [5]. In a recent report, vitamin B12 deficiency was observable in 0.54\% of patients with $\mathrm{HL}$ and anemia [6].

Keywords: Hodgkin Lymphoma, Tuberculosis, Radiology

Anahtar Sözcükler: Hodgkin Lenfoma, Tüberküloz, Radyoloji

Conflict of Interest: The authors of this paper have no conflicts of interest including specific financial interests, relationships, and/or affiliations relevant to the subject matter or materials included.

\section{References}

1. Büyükşimşek $M$, Paydaş $S$, Gumurdulu $D$, Mirili $C$, Oğul $A$, Yetişir $A E$, Tohumcuoğlu M. Atypical radiologic image characterized by cavitary lung lesions in a case of Hodgkin lymphoma. Turk J Hematol 2019;36:6061. 
2. Hedley DW, Hallahan AR, Tripp EH. Flow cytometric measurement of glutathione content of human cancer biopsies. Br J Cancer 1990;61:65-68.

3. Cao R, Teskey G, Islamoglu H, Abrahem R, Munjal S, Gyurjian K, Zhong $L$, Venketaraman V. Characterizing the effects of glutathione as an immunoadjuvant in the treatment of tuberculosis. Antimicrob Agents Chemother 2018:62.

4. Kilfoil KM, Mayne E, Scott L, Stevens W. A high burden human immunodeficiency virus and tuberculosis resource limited setting, gains from including Xpert MTB/RIF in the diagnostic algorithm of fluid specimens submitted for exclusion of lymphoma by immunophenotypic analysis. PLoS One 2015;10:e0134404.

5. Nakasone $E$, Mato $N$, Nakayama $M$, Bando $M$, Sugiyama $Y$. A case of pulmonary tuberculosis with false negative QuantiFERON TB-2G Test. Kekkaku 2012;87:9-13.

6. Yasmeen T, Ali J, Khan K, Siddiqui N. Frequency and causes of anemia in lymphoma patients. Pak J Med Sci 2019;35:61-65.

๑Copyright 2019 by Turkish Society of Hematology

Turkish Journal of Hematology, Published by Galenos Publishing House

Address for Correspondence/Yazışma Adresi: Sora YASRI, M.D., KMT Primary Care Center, Bangkok, Thailand E-mail : sorayasri@outloook.co.th ORCID: orcid.org/0000-0001-8292-6656
Received/Geliş tarihi: August 04, 2019 Accepted/Kabul tarihi: August 07, 2019

DOI: 10.4274/tjh.galenos.2019.2019.0291

\section{Reply from the Authors}

\section{To the Editor,}

We thank Drs. Yasri and Wiwanitkit for their interest and for sharing their thoughts on our case report. We agree with them about the co-occurrence of tuberculosis and lymphoma, especially in endemic areas. Additionally, it is very well known that infections with Mycobacterium tuberculosis and other intracellular microorganisms are common in cases of Hodgkin lymphoma (HL) due to underlying T-cell defects $[1,2]$. On the other hand, clinical symptoms and signs including fever, night sweats, and weight loss are very common in tuberculosis and in $\mathrm{HL}$, and sometimes it may be very difficult to differentiate $\mathrm{HL}$ and/or accompanying tuberculosis in a case of HL. For this reason, as we discussed before, tuberculosis was the first diagnosis in our case when the patient presented with fever and night sweats. To differentiate and to exclude tuberculosis, we tried different technologies, including culture for tuberculosis and follow-up radiologic imaging, and also clinical signs and symptoms. Of course QuantiFERON was not the only applied test in our case, but due to the journal's space limitations we could not mention the other tests: culture for tuberculosis was reported as negative and the patient responded very well to anti-lymphoma therapy only.

\section{References}

1. Roux M, Schraven B, Roux A, Gamm H, Mertelsmann R, Meuer S. Natural inhibitors of T cell activation in Hodgkin's disease. Blood 1991;78:2365-2371.

2. Melero M, Gennaro O, Domínguez C, Sánchez Avalos JC. Tuberculosis in patients with lymphomas. Medicina (B Aires) 1992;52:291-295. 